\title{
Electro-oxidation of chlorophenols at glassy carbon electrodes modified with polyNi(II)complexes
}

\author{
Cristhian Berríos $^{\mathrm{a}}$, José F. Marco ${ }^{\mathrm{b}}$, Claudio Gutiérrez ${ }^{\mathrm{b}}$, María Soledad Ureta-Zañartu ${ }^{\mathrm{a}, *}$ \\ a Facultad de Química y Biología, Departamento de Ciencias del Ambiente, Universidad de Santiago de Chile (USACh), casilla 40, correo 33, Santiago, Chile \\ b Instituto de Química Física “Rocasolano”, CSIC, C. Serrano, 119, 28006, Madrid, Spain
}

\section{A R T I C L E I N F O}

\section{Article history:}

Received 22 March 2009

Received in revised form 3 June 2009

Accepted 6 June 2009

Available online 16 June 2009

Keywords:

Chlorophenols electro-oxidation

Glassy carbon modified electrode

PolyNi(II)p-phenylporphyrins films

PolyNi(II) phthalocyanines films

\begin{abstract}
A B S T R A C T
The effect of the ligand macrocycle (phenylporphyrin (PP) or phthalocyanine (Pc)) and of the ligand substituent $\left(-\mathrm{NH}_{2}\right.$ or $-\mathrm{SO}_{3}{ }^{-}$) on the catalytic activity for the electro-oxidation in a pH 11 buffer electrolyte of 2- and 4-chlorophenol (2-CP and 4-CP), 2,4- and 2,6-dichlorophenol (2,4-DCP and 2,6-DCP), 2,4,6-trichlorophenol (2,4,6-TCP), and pentachlorophenol (PCP) at glassy carbon electrodes modified with electropolymerized $\mathrm{Ni}$ (II) macrocycles was studied. The polyphenolic residue deposited at the electrode surface was characterized by cyclic voltammetry, impedance measurements, ex situ Fourier transform infrared spectroscopy (FT-IR) and X-ray Photoelectron Spectroscopy (XPS). A band of aliphatic C=O stretching in the IR spectrum of the fouling film produced by potential cycling in 2,4,6-TCP indicated that the aromatic ring had been broken, yielding ketones, aldehydes and/or carboxylic acids. The sulphonated $\mathrm{Ni}(\mathrm{II})$ polymers, which showed the $\mathrm{Ni}(\mathrm{III}) / \mathrm{Ni}(\mathrm{II})$ process in the $\mathrm{CV}$, had XP spectra typical of paramagnetic $\mathrm{Ni}(\mathrm{II})$, indicating that they contained $\mathrm{Ni}(\mathrm{OH})_{2}$ clusters. On the contrary, the CVs of the amino $\mathrm{Ni}(\mathrm{II}) \mathrm{did}$ not show the $\mathrm{Ni}(\mathrm{III}) / \mathrm{Ni}(\mathrm{II})$ process at all, this process appearing only after previous activation by potential cycling, and only to a small extent. As was to be expected, the XP spectra of activated amino films corresponded to diamagnetic $\mathrm{Ni}(\mathrm{II})$, showing that the concentration of $\mathrm{Ni}(\mathrm{OH})_{2}$ clusters was very small. The amino films were less active than the sulpho films for the oxidation of chlorophenols, in agreement with the lower concentration of $\mathrm{Ni}(\mathrm{OH})_{2}$ clusters in the former films. For all electrodes the highest activity was observed for 2,4,6-TCP, since its oxidation yields a phenolic residue which is much more porous than those produced by the other CPs.
\end{abstract}

(C) 2009 Elsevier Ltd. All rights reserved.

\section{Introduction}

Chlorophenols (CPs), common pollutants in many industrial wastewaters, are used as pesticides, paint preservatives and cellulose bleaching agents. They are highly toxic and persistent, and thus their recovery or mineralization is a must. The phenolic $\mathrm{OH}$ group confers the CPs solubility in water, the ionized form being more hydrophilic, while the neutral form is more lipophilic and has higher membrane permeability [1,2]. The $\mathrm{p} K_{\mathrm{a}}$ value depends on the number of chlorine atoms and on their position with respect to the OH group [3-5], increasing from 4.7 for pentachlorophenol up to 9.4 for 2-chlorophenol. We reported a linear correlation between the anodic peak potential of several CPs on glassy carbon (GC) at pH 11 and the $\mathrm{p} K_{\mathrm{a}}$, the oxidation being the more facile the less acidic was the $\mathrm{CP}$ [4]. The formation of the polyphenolic film began at a lower potential for 2-CP and 2,4-DCP than for 2,4,6-TCP, and the film on the latter was so porous that it allowed the oxidation of $2,4,6-\mathrm{TCP}$

\footnotetext{
* Corresponding author.

E-mail address: soledad.ureta@usach.cl (M.S. Ureta-Zañartu).
}

to continue [4]. The first charge-transfer step is rate-determining and yields the corresponding phenoxy radical.

Abgoola et al. [6] studied the electro-oxidation of CPs at gold electrodes modified with electropolymerized $\mathrm{Ni}(\mathrm{II})$ tetrakisbenzylmercapto-and $\mathrm{Ni}(\mathrm{II})$ dodecylmercapto-phthalocyanines, and found that activation of the "O-Ni-O" bridge yielded poly $\mathrm{Ni}(\mathrm{OH})$ NiPcs, which showed a better catalytic activity than the unactivated polyNiPcs, although eventually all the electrodes became fouled by deposition of oligomers [7-11]. Coteiro et al. [12] propose that the electro-oxidation of 4-CP in acidic media on $\mathrm{Ti} / \mathrm{Ru}_{0.3} \mathrm{M}_{0.7} \mathrm{O}_{2}$ with $\mathrm{M}=\mathrm{Ti}$ or $\mathrm{Sn}$ could yield the easily mineralized oxalic acid via 4-chlorocatechol or via hydroquinonebenzoquinone-malic acid-maleic acid.

Nickel tetraazamacrocyclic complexes are exceptionally efficient and selective electrocatalysts $[6,13,14]$, probably because nickel easily changes from a square planar to an octahedral conformation $[15,16]$. When planar $\mathrm{Ni}(\mathrm{II})$-phthalocyanine and porphyrin tetrasulphonated complexes are electrodeposited in aqueous media they form a stacked structure on the electrode surface [6], film growth being proposed to occur via $\mathrm{Ni}-\mathrm{O}-\mathrm{Ni}$ bridges, with the formation of some nickel hydrox- 
ide nanostructures $[17,18]$. In these modified electrodes the oxidation of $\mathrm{Ni}(\mathrm{II})$ occurs with water expulsion, probably due to the hydrophobic character of the macrocyclic ligands [19]. Revenga-Parra et al. [20] found that GC electrodes modified with films of $\mathrm{Ni}(\mathrm{II})-\left(\mathrm{N}, \mathrm{N}^{\prime}\right.$-bis(2,5-dihydroxybenzylidene)-1,2diaminobenzene) (Ni(II)-DHS]/GC) show electrocatalytic activity for methanol oxidation.

Previous studies in our laboratory indicate that polyNiTSPcmodified GC electrodes are less fouled by the electro-oxidation of 2-CP than bare GC [21]. Other authors have reported similar results for the oxidation of organic molecules at electrodes modified with different $\mathrm{Ni}(\mathrm{II})$ complexes $[17,22,23]$. We have reported [16] that the half-sum potential of the $\mathrm{Ni}(\mathrm{III}) / \mathrm{Ni}(\mathrm{II})$ process at $\mathrm{GC}$ modified electrodes in a pH 11 buffer electrolyte is almost independent of the ligand (phthalocyanines (Pc) or phenylporphyrins $(\mathrm{PP})$ ) and of the substituent (amino or sulphonated group). Francisco et al. [24] attributed to the $\mathrm{Ni}(\mathrm{III}) / \mathrm{Ni}(\mathrm{II})$ redox couple the activity for the oxidation of hydroquinone and 4-aminophenol of a carbon-paste electrode modified with $\mathrm{SiO}_{2} / \mathrm{Nb}_{2} \mathrm{O}_{5}$-phosphate on which $\mathrm{Ni}$ (II)porphyrin had been previously adsorbed. However, Yi et al. [25] and Agboola et al. [6] recently reported the electro-oxidation of dopamine and CPs on electrodes modified with different electropolymerized films of nickel(II) complexes, although the $\mathrm{Ni}(\mathrm{III}) / \mathrm{Ni}$ (II) couple did not appear in the CVs. Probably the activity was due to a $\pi-\pi$ interaction similar to that reported for polymeric adsorbents chemically modified with porphyrins, on which the retention of phenol and CPs is increased by this interaction [26].

In this work we have studied the effect of the ligand macrocycle, and of the ligand substituent, on the catalytic activity for oxidation at $\mathrm{pH} 11$ of CPs at polyNi(II)phthalocyanine/GC (polyNiPc/GC) and polyNi(II)phenylporphyrin/GC (polyNiPP/GC) electrodes, both tetrasulpho- (TS) and tetraamino-(TA) substituted.

\section{Experimental}

\subsection{Electrode preparation}

As in previous work [18] two water-soluble Ni(II)complexes, tetrasulphophthalocyanine (NiTSPc) and tetrasulphophenylporphyrin (NiTSPP), and two water-insoluble Ni(II) compounds, $\mathrm{Ni}(\mathrm{II})$ tetraaminophthalocyanine (NiTAPc) and $\mathrm{Ni}(\mathrm{II})$ tetraaminophenylporphyrin (NiTAPP), were used. The respective structures are given in Fig. 1. The Ni complexes (Aldrich for NiTSPc, and Fron- tier Scientific, Utah, for the other three complexes) and all other chemicals were used as received.

A GC substrate (Pine Instruments, $0.8 \mathrm{~cm}$ in diameter) was used for the electrochemical experiments, Pt foil (Aldrich, 99.99\%) for FTIRS, and ITO (Delta Technology) for XPS [18]. The substrate (except the ITO plates, which were used only once) was cleaned with piranha solution, rinsed with distilled water, polished to a mirrorlike finish with $0.05 \mu \mathrm{m}$ alumina (Buehler), rinsed with water, and sonicated in a water bath for $10 \mathrm{~min}$. GC was then subjected to repetitive cyclic voltammetry (RCV) at $0.1 \mathrm{~V} \mathrm{~s}^{-1}$ in $0.5 \mathrm{M} \mathrm{H}_{2} \mathrm{SO}_{4}$ until the double-layer current decreased to a given value, and then activated by RCV (2-10 scans) in $0.1 \mathrm{M} \mathrm{NaOH}$.

The tetrasulpho films were formed by RCV (20 scans) between -0.20 and $0.84 \mathrm{~V}$ vs. mercurous sulphate electrode (MSE) at $10 \mathrm{mV} \mathrm{s}^{-1}$ in a $0.1 \mathrm{M} \mathrm{NaOH}+1 \mathrm{mM}$ NiTSPc or NiTSPP solution, at room temperature and under nitrogen, and the modified electrode was stabilized by $5 \mathrm{CVs}$ in a pH 11 carbonate-hydrogen carbonate buffer electrolyte. (All potentials are referred to the mercurous sulphate electrode, MSE (0.64 V vs. SHE)).

The tetraamino-phthalocyanine and -porphyrin films were obtained by RCV in a $1 \mathrm{mM}$ solution of the complex in DMF and ACN, respectively, using $1 \mathrm{mM}$ tetrabutylammonium perchlorate (TBAP) as support electrolyte. The $\mathrm{Ni}(\mathrm{III}) / \mathrm{Ni}(\mathrm{II})$ process, which was completely absent in the as-deposited amino films, was activated by 80 RCVs in $0.1 \mathrm{M} \mathrm{NaOH}$ for PP complexes and in the $\mathrm{pH} 11$ buffer for Pc complexes.

\subsection{Electrode characterization}

The impedance measurements were carried out with an Autolab PGSTAT30 (Eco Chemie, The Netherlands), at constant potential using a $5 \mathrm{mV}$ rms sinusoidal modulation in the $10 \mathrm{kHz}$ to $10 \mathrm{mHz}$ frequency range with a logarithmic distribution (10 steps per decade) over a period of about $30 \mathrm{~min}$ at each potential.

The ex situ FT-IR experiments were carried out under a vacuum of 14 mbar on a Bruker IFS 66 V FT-IR-spectrometer equipped with a variable-angle specular reflectance accessory at an incidence angle of $45^{\circ}$. A total of 100 interferometric scans were accumulated for each spectrum. The IR spectra are given as $R_{S} / R_{r}$, where $R_{\mathrm{S}}$ and $R_{\mathrm{r}}$ are the reflected intensities of the sample and of the reference, respectively. The reference was always a clean Pt electrode.

$\mathrm{X}$-ray photoelectron spectra (XPS) were recorded using a triplechanneltron CLAM2 analyzer [21].
(A)

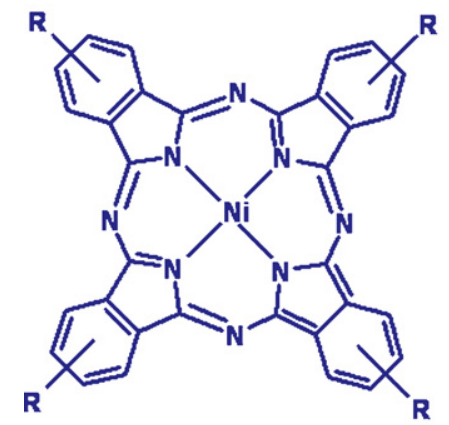

(B)

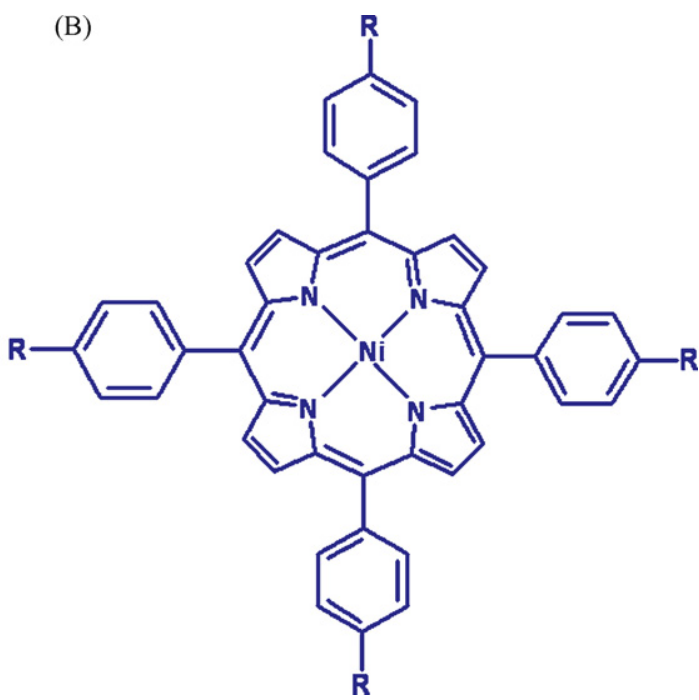

Fig. 1. Structures of (A) $\mathrm{Ni}(\mathrm{II})$ tetraazaphthalocyanine and (B) $\mathrm{Ni}(\mathrm{II})$ tetraphenylporphyrin. In both complexes $\mathrm{R}$ can be $-\mathrm{SO}_{3}$ or $-\mathrm{NH}_{2}$. 


\section{Results and discussion}

\subsection{PolyNiTSPC/GC electrode}

\subsubsection{Cyclic voltammetry (CV)}

The first (thick line), second (dotted line) and fifth (dashed line) CVs, with electrolyte stirring between successive scans, of a polyNiTSPc/GC electrode in $1 \mathrm{mM}$ solutions of $2-$ and 4-chlorophenol (2-CP and 4-CP), 2,4- and 2,6-dichlorophenol (2,4-DCP and 2,6-DCP), 2,4,6-trichlorophenol (2,4,6-TCP), and pentachlorophenol (PCP) are given in Fig. 2. The thin lines are the CVs of the modified electrodes in the support electrolyte. All the CVs show an irreversible anodic peak (peak Ia in Fig. 2) of CP oxidation at $0.2-0.3 \mathrm{~V}$ vs. MSE [21], this peak being the same as that obtained at a bare GC electrode, but with a higher current, probably due to accumulation of the $\mathrm{CP}$ in the polymeric film. Peak IIa corresponds to the oxidation of $\mathrm{Ni}(\mathrm{II})$ together with that of $\mathrm{CP}$, which is postulated to occur by a chemical reaction with $\mathrm{Ni}(\mathrm{III})$ followed by a reoxidation of $\mathrm{Ni}(\mathrm{II})$ [21]. The reduction of $\mathrm{Ni}$ (III) (peak IIIc) is barely affected by the CPs.

Fouling is worst for $4-\mathrm{CP}($ Fig. $2 \mathrm{~B})$, so much so that even the $\mathrm{Ni}(\mathrm{III}) / \mathrm{Ni}$ (II) process is no longer seen in the fifth $\mathrm{CV}$ (Fig. 2B, dotted line), in agreement with previous results [18]. For 2-CP(Fig. 2A), 2,4DCP (Fig. 2C) and 2,6-DCP (Fig. 2D) fouling is smaller than for bare GC, and 2,4,6-TCP (Fig. 2E) and PCP (Fig. 2F) show no fouling, probably because after the first electron transfer, the loss of chloride ion would be slow. In a recent work with electrochemical impedance, we found that the polyphenolic film formed with 2,4,6-TCP is much more porous than the films formed with 2-CP and 2,4-DCP [16].

Except for 4-CP a cathodic peak, peak IVc, without a corresponding anodic peak, appeared in the negative scan at around $-0.2 \mathrm{~V}$ for mono- and di-CPs and around $-0.5 \mathrm{~V}$ for $2,4,6-\mathrm{TCP}$ and PCP, the

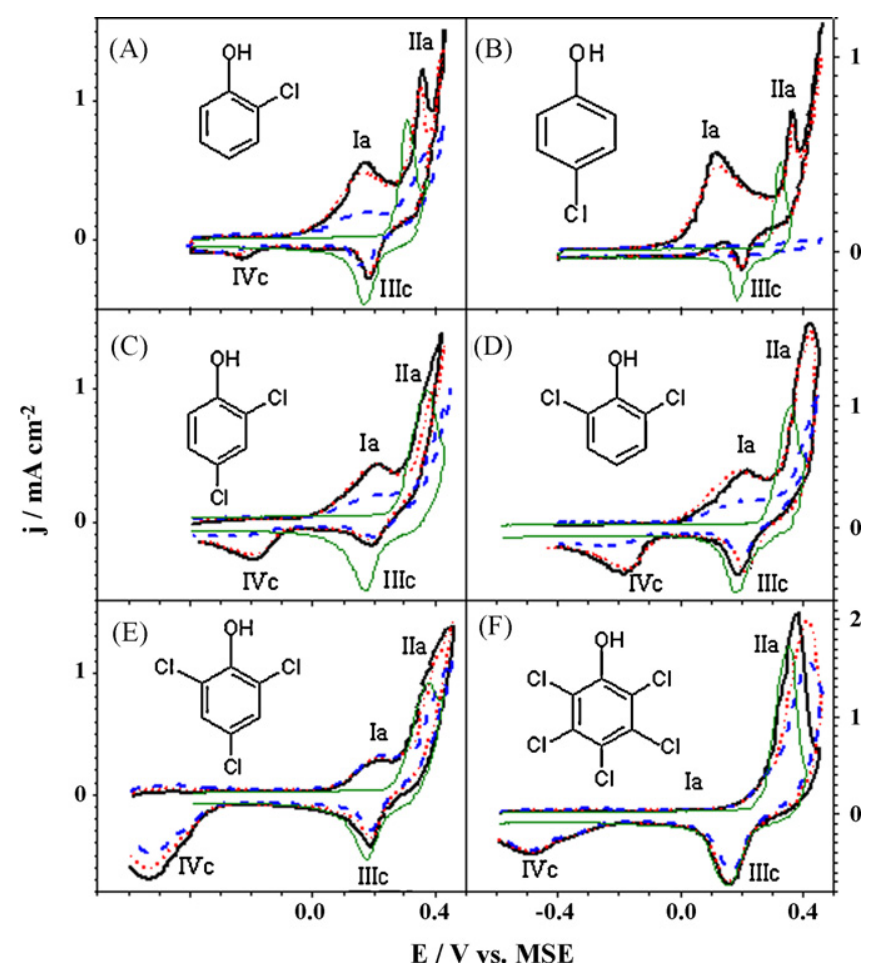

Fig. 2. $1 \mathrm{st}$ (thick solid line), 2 nd (dotted line) and 5 th (dashed line) $\mathrm{CVs}$ at $0.1 \mathrm{Vs}^{-1}$ in a pH 11 buffer electrolyte: (A) 2-CP; (B) 4-CP; (C) 2,4-DCP; (D) 2,6-DCP; (E) 2,4,6TCP; and (F) PCP, on a polyNiTSPc/GC electrode. The concentration of the CPs was always $1 \mathrm{mM}$. The electrolyte was stirred after each $\mathrm{CV}$. The thin line is the $\mathrm{CV}$ of the polyNiTSPc in the absence of CP. The PCDs parameters at $0.1 \mathrm{~V} \mathrm{~s}^{-1}$ were: (A) 0.87 ; (B) 0.44 ; (C) 0.98 ; (D) 1.01 ; (E) 0.90 ; (F) $1.70 \mathrm{~mA} \mathrm{~cm}^{-2}$.

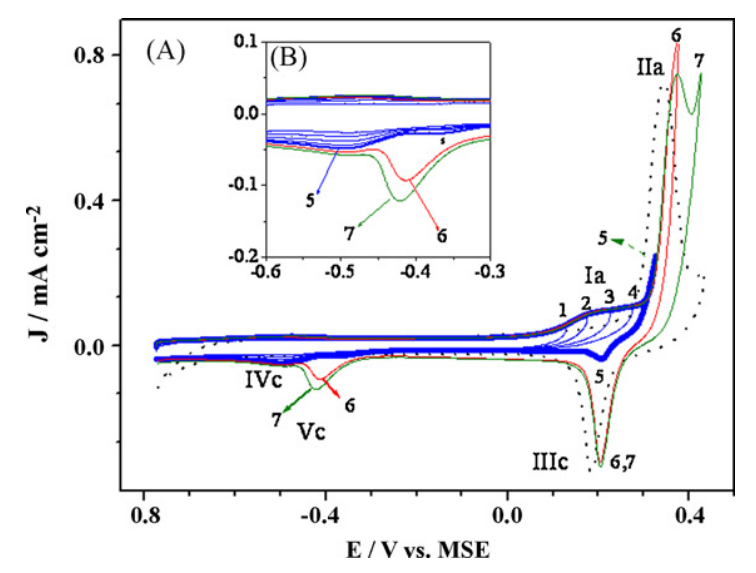

Fig. 3. $\mathrm{CVs}$ at $0.05 \mathrm{~V} \mathrm{~s}^{-1}$ with increasing positive potential limit ( $\left.\mathrm{E}_{\mathrm{pos}}\right)$ of $1 \mathrm{mM} 2,4,6-$ TCP (in a pH 11 buffer electrolyte) on a polyNiTSPc/GC electrode. $\mathrm{E}_{\text {pos }}$ : (1): $0.13 \mathrm{~V}$; (2) $0.18 \mathrm{~V}$; (3): $0.23 \mathrm{~V}$; (4) 0.28 (V); (5, thick line): $0.33 \mathrm{~V}$; (6): $0.38 \mathrm{~V}$; and (7): $0.43 \mathrm{~V}$. The dotted line is the CV in the absence of CP. PCD at $0.05 \mathrm{~V} \mathrm{~s}^{-1}: 0.72 \mathrm{~mA} \mathrm{~cm}^{-2}$.

peak current density being the highest for 2,4,6-TCP. This peak has been attributed, in the case of 2,4,6-TCP at a GC electrode, to a soluble quinonic-like structure, whose formation would require the expulsion of the chlorine atom in position 4 [4].

CVs at $0.05 \mathrm{~V} \mathrm{~s}^{-1}$ of $1 \mathrm{mM} 2,4,6-\mathrm{TCP}$ at a polyNiTSPc/GC electrode, with increasing positive potential limit from 0.13 to $0.43 \mathrm{~V}$ at $50 \mathrm{mV}$ intervals, and with stirring of the electrolyte between successive CVs, are given in Fig. 3. The dotted line is the CV in the $\mathrm{pH}$ 11 base electrolyte. In the first four scans 2,4,6-TCP oxidation takes place on the GC substrate, before Ni(II) oxidation, yielding a species which is reduced in the cathodic peak IVc, which increases when the $\mathrm{E}_{\text {pos }}$ reaches $0.33 \mathrm{~V}$ (curve 5, thick solid line). At this potential $\mathrm{Ni}$ (II) oxidation begins, positively shifted by $30 \mathrm{mV}$ with respect to that in buffer electrolyte (dotted line), indicating a slight inhibition by $2,4,6$-TCP. With $E_{\text {pos }}=0.38$ and $0.43 \mathrm{~V}$ nearly full oxidation of $\mathrm{Ni}(\mathrm{II})$ is achieved, as evidenced by the $\mathrm{Ni}(\mathrm{III})$ reduction peak, whose charge is practically the same as that in buffer electrolyte. A new cathodic peak, peak Vc, appears at $-0.4 \mathrm{~V}$, and must correspond to a species formed at peak Ila.

\subsubsection{Electrochemical impedance}

We have already reported the impedance response of polyNiTSPc/GC electrodes [18] and of the oxidation of CPs at bare GC [4], and, in order to facilitate comparison, in this work we have used the same procedure. Sample 1 was a fresh polyNiTSPc/GC electrode (previously stabilized by 5 CVs in the $\mathrm{pH} 11$ buffer electrolyte and characterized by its peak current density at $0.1 \mathrm{~V} \mathrm{~s}^{-1}\left(P C D_{0.1}\right)$ for the $\mathrm{Ni}(\mathrm{III}) / \mathrm{Ni}(\mathrm{II})$ process $)$ in $1 \mathrm{mM} \mathrm{CP}$ in the same buffer; sample 2 is the same electrode after $5 \mathrm{CVs}$ in $1 \mathrm{mM} \mathrm{CP}$, and sample 3 is the same electrode used for $\mathrm{CP}$ oxidation but in the absence of $\mathrm{CP}$ in the solution, in order to detect any fouling film on the electrode surface. Fig. 4 shows the Nyquist plots of a polyNiTSPc/GC electrode in the $\mathrm{pH} 11$ buffer electrolyte plus $1 \mathrm{mM}$ 2-CP (open squares); 2,4-DCP (closed circles) and 2,4,6-TCP (open triangles) at different potentials. The asterisks correspond to polyNiTSPc/GC in base electrolyte. The polyNiTSPc/GC/electrolyte interphase is not easily correlated with an equivalent circuit [18]. As in previous works [4,18], Randles' equivalent circuit, $R_{\mathrm{u}}-C_{\mathrm{dl}} / / Z_{\mathrm{f}}$, was used, where $R_{\mathrm{u}}$ is the uncompensated resistance of electrolyte and polyNiTSPc film, $C_{\mathrm{dl}}$ is the double-layer capacitance, and $Z_{\mathrm{f}}$ is the charge-transfer impedance, composed of the charge-transfer resistance, $R_{\mathrm{ct}}$, plus the Warburg impedance, $Z_{\mathrm{w}}$. (Actually no evidence of a Warburg impedance was found in any of the systems). $R_{\mathrm{u}}$ was evaluated as the intercept of the curve with the x-axis at high frequency, whereas $R_{\mathrm{ct}}$ and $C_{\mathrm{dl}}$ were obtained by fitting the points to a semicircle, preferably using the low-frequency region. The values so obtained are shown in Table 1. 

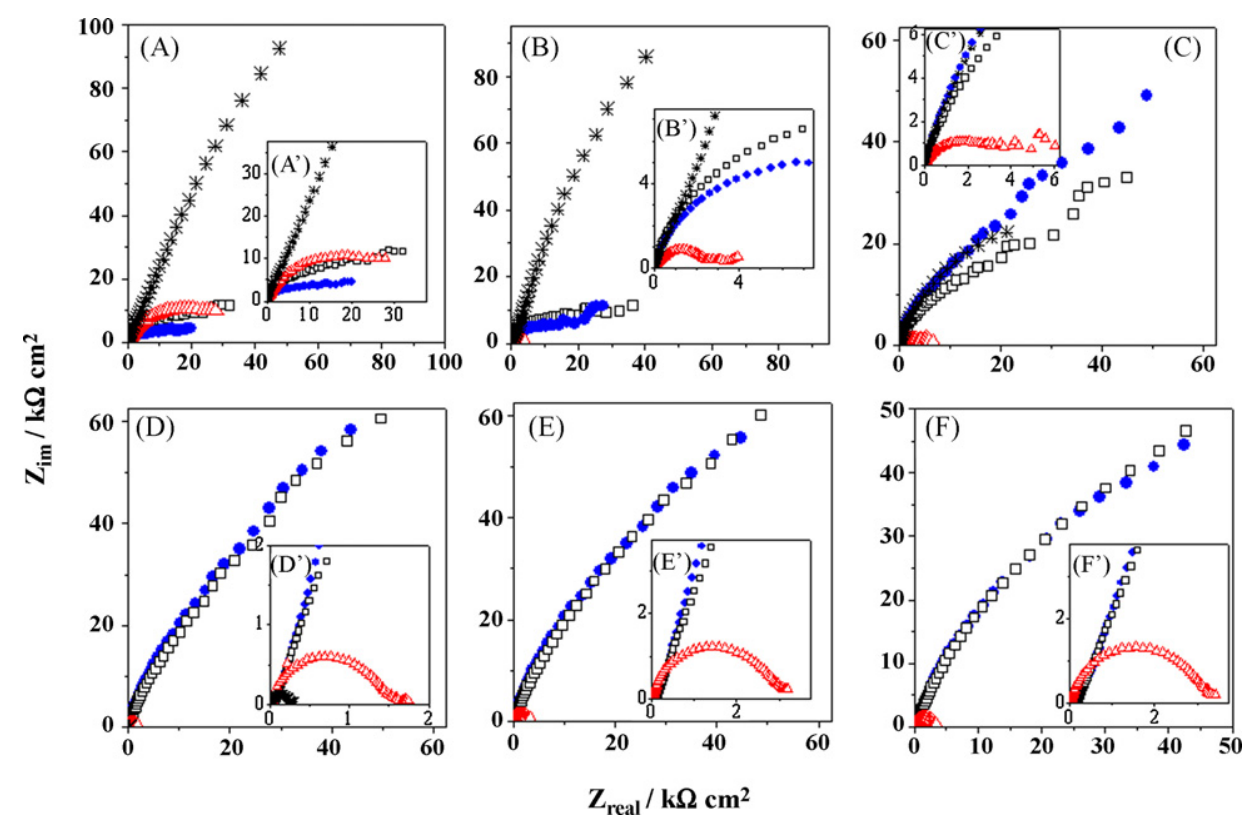

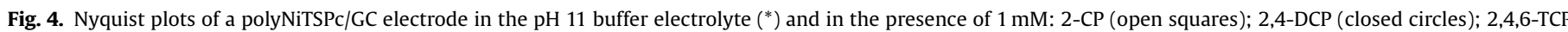
(open triangles), at the following potentials: (A) $0.05 \mathrm{~V}$; (B) $0.15 \mathrm{~V}$; (C) $0.25 \mathrm{~V}$; (D) $0.35 \mathrm{~V}$; (E) $0.45 \mathrm{~V}$; (F) $0.55 \mathrm{~V}$ vs. MSE.

With 2-CP and 2,4-DCP there appeared no semicircle at any potential, because the high oxidation currents that preceded $\mathrm{Ni}(\mathrm{II})$ oxidation led to the formation of thick fouling films that largely impeded any faradaic reaction to occur. However, $R_{\mathrm{ct}}$ and $C_{\mathrm{dl}}$ could be evaluated from the data at high frequencies. At 0.05 and $0.15 \mathrm{~V}$ their $Z_{\text {im }}$ values were much lower than those in buffer electrolyte, in which, for an electrode with $\mathrm{PCD}_{0.1}=0.54 \mathrm{~mA} \mathrm{~cm}{ }^{-2}, C_{\mathrm{dl}}$ was about $180 \mu \mathrm{F} \mathrm{cm}^{-2}$ at $0.30 \mathrm{~V}$, and decreased slowly with increasing potential (Fig. $4 \mathrm{~A}$ and B) [18]. At $0.25 \mathrm{~V}$ the $Z_{\text {im }}$ values were similar to those in buffer electrolyte (Fig. 4C), but higher at higher potentials, at which there is $\mathrm{Ni}$ (II) oxidation (Fig. 4D-F). Note in the inset $\mathrm{D}$ in Fig. $4 \mathrm{D}$ that, in agreement with our previous work [18], at $0.35 \mathrm{~V} R_{\mathrm{ct}}$ is very small in buffer electrolyte, evidencing that $\mathrm{Ni}(\mathrm{II})$ oxidation is occurring.

The Nyquist plot with 2,4,6-TCP (open triangles in Fig. 4) shows a charge-transfer process from $0.15 \mathrm{~V}$ (Fig. 4B), before $\mathrm{Ni}$ (II) oxidation starts, confirming that oxidation of 2,4,6-TCP takes place at GC sites [4], due to the high porosity of the film [18]. The $R_{\mathrm{ct}}$ is the lowest of the three CPs tested (Table 1 ).

The uncompensated resistance with 2-CP and 2,4-DCP (Table 1) increases with increasing potential, evidencing the formation of a non-conducting fouling film of increasing thickness, as reported for a GC electrode [4]. On the contrary, the uncompensated resistance with 2,4,6-TCP remains almost constant, showing the absence of fouling, its value being very similar to those of a fresh polyNiTSPc/GC electrode [18].
The double-layer capacity increased slowly with increasing potential for the three CPs, and was higher for 2,4,6-TCP, this in turn being about $2 / 3$ of that in background electrolyte.

None of the Nyquist plots, not even those with 2,4,6-TCP, show a segment of unit slope at low frequencies, i.e. in no case the oxidation of the CP involves a Warburg process. Consequently, the $Z_{\mathrm{w}}$ parameter was not evaluated. A fresh polyNiTSPc/GC electrode did show diffusion control in buffer electrolyte.

In conclusion, 2-CP and 2,4-DCP apparently react in the same way at bare GC and at polyNiTSPc/GC electrodes, whereas 2,4,6-TCP shows less fouling at modified GC.

Plots of the logarithm of the impedance as a function of the potential at constant frequencies are given in Fig. 5 for the three samples obtained with each of three CPs. For 2-CP (Fig. 5A-C) the fouling film appears already at $0.25 \mathrm{~V}$ (Fig. 5A), as evidenced by the increase at this potential of $\log Z$ at high frequencies, i.e. of $R_{\mathrm{u}}$. The fouling film remains in samples 2 and 3 (Fig. 5B and C). Similar results were obtained for 2,4-DCP (Fig. 5D-F), in agreement with the results observed in Fig. $2 \mathrm{~A}$ and $\mathrm{C}$, where both CPs shows similar evidence of electrode fouling in their CVs. However, the $R_{\mathrm{u}}$ of sample 2 was much lower than that of sample 1 .

For 2,4,6-TCP $R_{\mathrm{u}}$ was constant, and the same in the three samples, evidencing an absence of fouling similar to that reported for bare GC electrodes [18]. Therefore, the chlorophenoxy radical formed in the rate-determining step (rds) undergoes further charge-transfer reactions, rather than undergoing polymerization.

Table 1

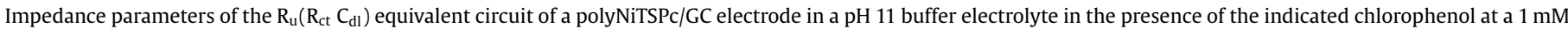
concentration.

\begin{tabular}{|c|c|c|c|c|c|c|c|c|c|}
\hline \multirow[t]{2}{*}{$\mathrm{E} / \mathrm{V}$} & \multicolumn{3}{|c|}{$2-\mathrm{CP}\left(\mathrm{PCD}=0.46 \mathrm{mAcm}^{-2}\right.$ at $\left.0.1 \mathrm{~V} \mathrm{~s}^{-1}\right)$} & \multicolumn{3}{|c|}{$2,4-\mathrm{DCP}\left(\mathrm{PCD}=0.61 \mathrm{~mA} \mathrm{~cm}^{-2}\right.$ at $\left.0.1 \mathrm{~V} \mathrm{~s}^{-1}\right)$} & \multicolumn{3}{|c|}{$2,4,6-\mathrm{TCP}\left(\mathrm{PCD}=0.60 \mathrm{~mA} \mathrm{~cm}^{-2}\right.$ at $\left.0.1 \mathrm{~V} \mathrm{~s}^{-1}\right)$} \\
\hline & $R_{\mathrm{u}} \Omega \mathrm{cm}^{2}$ & $R_{\mathrm{ct}} \mathrm{k} \Omega \mathrm{cm}^{2}$ & $\mathrm{C}_{\mathrm{dl}} \mu \mathrm{Fcm}^{-2}$ & $R_{\mathrm{u}} \Omega \mathrm{cm}^{2}$ & $R_{\mathrm{ct}} \mathrm{k} \Omega \mathrm{cm}^{2}$ & $C_{\mathrm{dl}} \mu \mathrm{F} \mathrm{cm}^{-2}$ & $R_{\mathrm{u}} \Omega \mathrm{cm}^{2}$ & $R_{\mathrm{ct}} \mathrm{k} \Omega \mathrm{cm}^{2}$ & $C_{\mathrm{dl}} \mu \mathrm{Fcm}^{-2}$ \\
\hline 0.05 & 22.3 & 9.24 & 42.0 & 20.7 & 3.96 & 47.6 & 20.3 & 10.7 & 59.1 \\
\hline 0.15 & 24.6 & 12.4 & 45.0 & 21.2 & 7.34 & 49.8 & 20.6 & $1.6 / 2.2^{*}$ & $51.4 / 85.4^{*}$ \\
\hline 0.25 & 39.2 & 11.8 & 52.0 & 30.0 & 14.5 & 64.9 & 20.8 & 1.84 & 56.0 \\
\hline 0.35 & 70.2 & 7.43 & 52.3 & 49.2 & 18.4 & 69.7 & 20.9 & 1.29 & 101 \\
\hline 0.45 & 102 & 16.6 & 62.3 & 57.0 & 17.8 & 69.5 & 21.0 & 2.61 & 93.7 \\
\hline 0.55 & 119 & 12.6 & 75.6 & 59.3 & 11.6 & 71.2 & 21.6 & 2.76 & 92.7 \\
\hline
\end{tabular}

\footnotetext{
* 2 semicircles at high and low frequencies, respectively.
} 


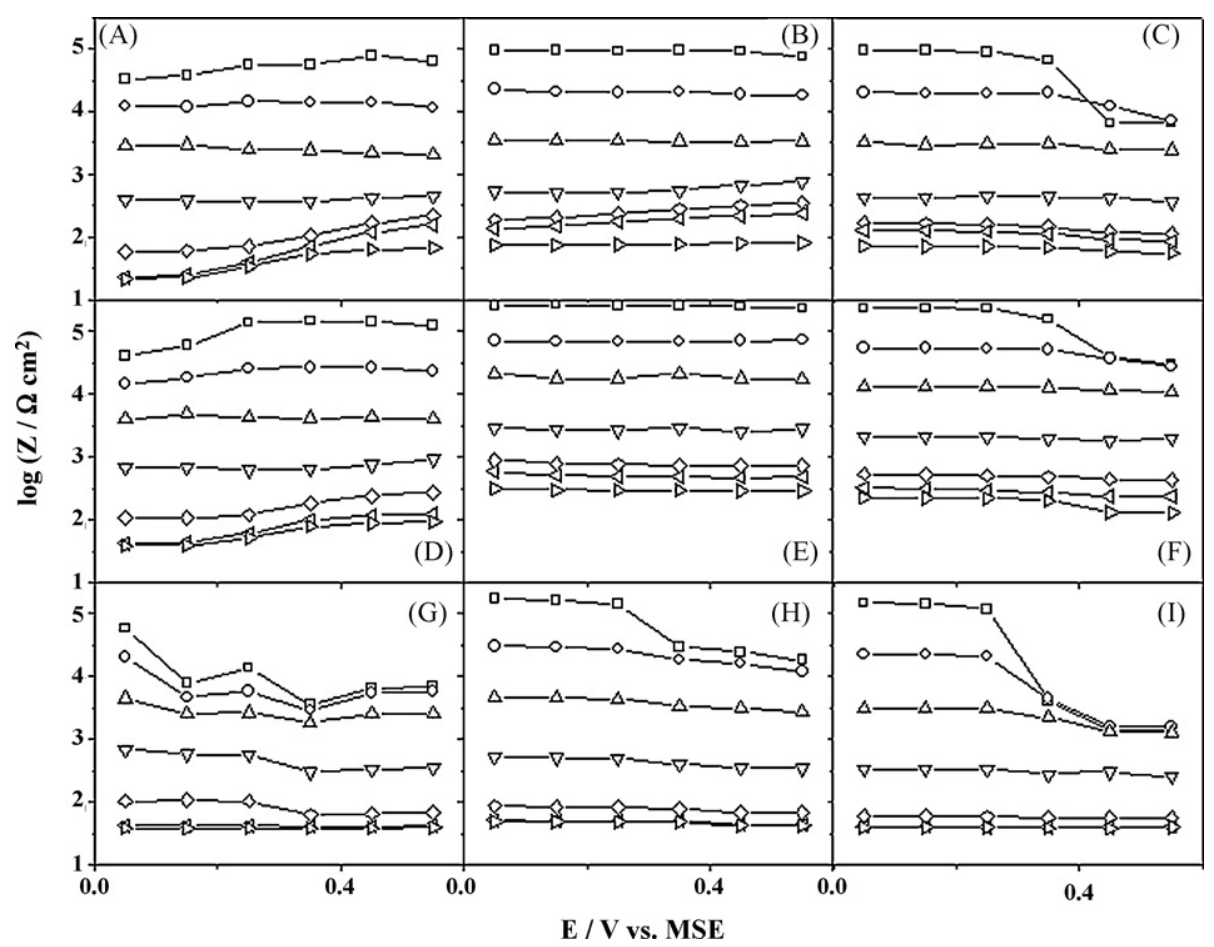

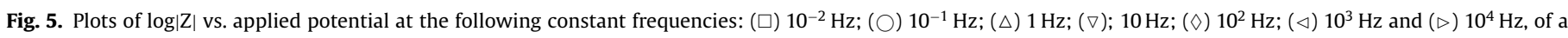

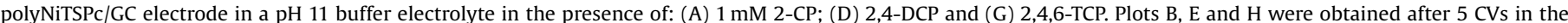

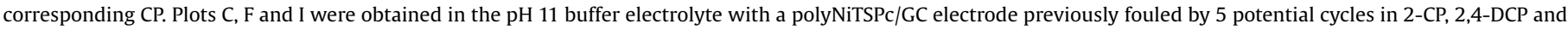
2,4,6-TCP, respectively.

For the three CPs the impedance at the lowest frequency of sample 3 decreases very much at about $0.4 \mathrm{~V}$, this decrease being obviously due to the onset of the $\mathrm{Ni}(\mathrm{II}) / \mathrm{Ni}$ (III) process. The decrease is higher for 2,4,6-TCP, in agreement with the much higher porosity of the fouling film.

\subsection{Effect of the ligand and substituent in the Ni(II) complexes}

\subsubsection{Cyclic voltammetry}

In order to study the role of the $\mathrm{Ni}(\mathrm{II})$ environment in the electrooxidation of CPs, three other polyNi(II)complexes/GC electrodes,

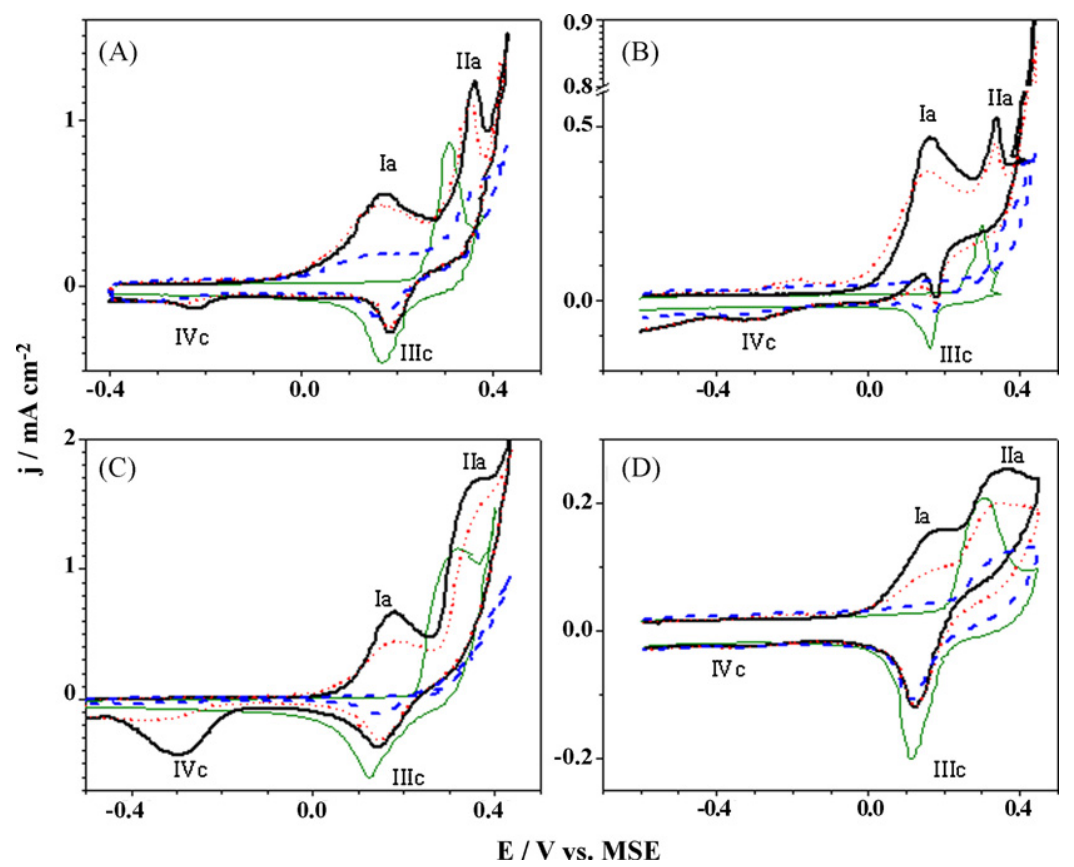

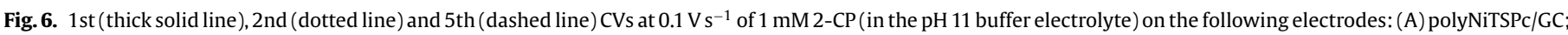

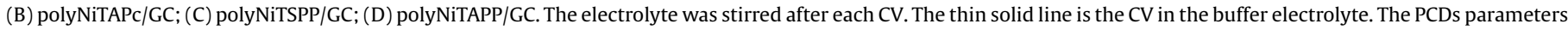
at $0.1 \mathrm{~V} \mathrm{~s}^{-1}$ were: (A) 0.85 ; (B) 0.22 ; (C) 1.16 ; (D) $0.21 \mathrm{~mA} \mathrm{~cm}^{-2}$. 

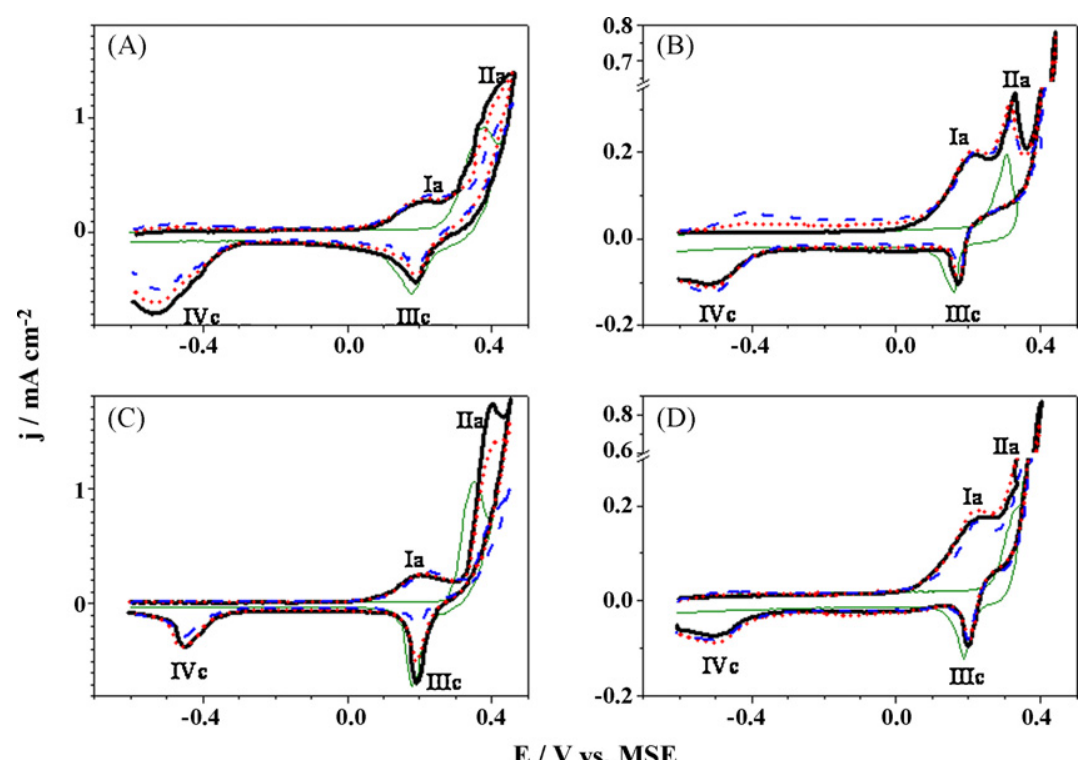

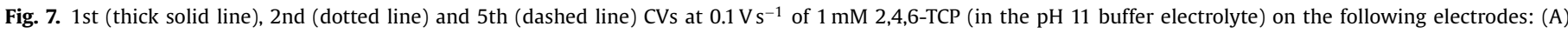

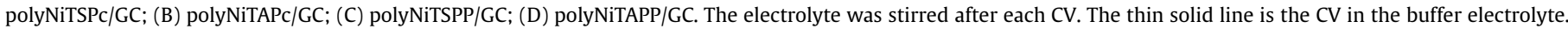
The PCDs parameters at $0.1 \mathrm{~V} \mathrm{~s}^{-1}$ were: (A) 0.90 ; (B) 0.19 ; (C) 1.05 ; (D) $0.18 \mathrm{~mA} \mathrm{~cm}^{-2}$.

prepared and characterized in previous works [16,18], were used for the oxidation of 2-CP and 2,4,6-TCP, selected as the CP showing the most difficult and the easiest, respectively, oxidation at the polyNiTSPc/GC electrode.

The 1st (thick line), 2nd (dotted line) and 5th (dashed line) CVs at $0.1 \mathrm{~V} \mathrm{~s}^{-1}$ of $1 \mathrm{mM} 2-\mathrm{CP}$ in the $\mathrm{pH} 11$ buffer electrolyte at GC modified: polyNiTSPc (A), activated polyNiTAPc (B), polyNiTSPP (C) and activated polyNiTAPP (D), are shown in Fig. 6, together with the corresponding CV in buffer electrolyte (thin line). The amino films were previously activated by 80 RCVs in alkaline media [16]. Previous results indicated that the amino film are less porous than the sulphonated ones [18], which would suggest that in the former film the $\mathrm{CP}$ could not reach the GC surface. However, the CVs in Fig. 6B clearly show that oxidation of $2-\mathrm{CP}$ at polyNiTAPc/GC precedes that of $\mathrm{Ni}(\mathrm{II})$, although the electrode becomes completely fouled after only 5 CVs. With activated polyNiTAPP also the oxidation of 2$\mathrm{CP}$ precedes that of $\mathrm{Ni}(\mathrm{II})$, and much of the $\mathrm{Ni}(\mathrm{III}) / \mathrm{Ni}(\mathrm{II})$ process remains in the 5 th $\mathrm{CV}$, although the electrode is also completely fouled (Fig. 6D). As could be expected, the CVs with polyNiTSPP/GC (Fig. 6C) are somewhat similar to those with polyNiTSPc, although fouling is much worse (Fig. 6A). A second reduction peak, peak IVc, is observed with the sulphonated polymers only, indicating that the amino substituent completely inhibit the formation of the corresponding oxidation products. A comparison of the CVs of the amino polymers (Fig. 6B and D) shows that substitution with Pc yields a more active polymer than substitution with PP.

The CVs of 2,4,6-TCP at the four modified GC electrodes are very similar (Fig. 7), no fouling being observed. The current increase at the more positive potentials observed with the amino films cannot be due to oxygen evolution, since no oxygen reduction peak appears. Peak IVc in Figs. 6 and 7 must be attributed to a $Q / \mathrm{H}_{2} \mathrm{Q}$ process, since in a second scan (not shown) the corresponding anodic process is observed.

It can be concluded that the activity of the polymeric $\mathrm{Ni}$ complexes for CP oxidation does not depend on the Ni ligand, PP or Pc, the role of the substituent (amino or sulphonate) being more important than that of the ligand, in agreement with a previous quantum chemical study [27].

Since the amino films have a low content of $\mathrm{Ni}(\mathrm{OH})_{2}$ species, they do not show a faradaic semicircle in the Nyquist plot, and, therefore, the results obtained are not shown.

\subsection{2. ex situ fourier transform infrared spectroscopy}

The ex situ FT-IR specular reflectance spectrum of polyNiTSPP/Pt and polyNiTAPP/Pt electrodes have been already reported [16], the skeletal bands of both PP complexes remaining in the polymeric film. In Fig. 8 we show the spectra of a fouled Pt electrode (A), a fouled polyNiTSPP/Pt electrode (B), and a fouled polyNiTAPP/Pt electrode (previously activated by 80 RCVs) (C), fouling being produced by 14,11 and $13 \mathrm{CVs}$ at $0.1 \mathrm{~V} \mathrm{~s}^{-1}$ in $1 \mathrm{mM} 2,4,6-\mathrm{TCP}$, respectively. A freshly cleaned Pt electrode was used as reference in all cases.

The spectrum of 2,4,6-TCP [28] has strong bands at $3520 \mathrm{~cm}^{-1}$ (OH stretching) and $3090 \mathrm{~cm}^{-1}$ (aromatic $\mathrm{C}-\mathrm{H}$ stretching). They appear clearly in the fouling film on Pt (Fig. 8A), and only the latter band in the fouling film on polyNiTAPP (Fig. 8C). Two bands at 2925 and $2841 \mathrm{~cm}^{-1}$ could be associated with the $\mathrm{O}-\mathrm{H}$ stretch and the C-H stretch, respectively, of a carboxylic acid [29]. No significant bands appeared between 2800 and $1800 \mathrm{~cm}^{-1}$ neither in

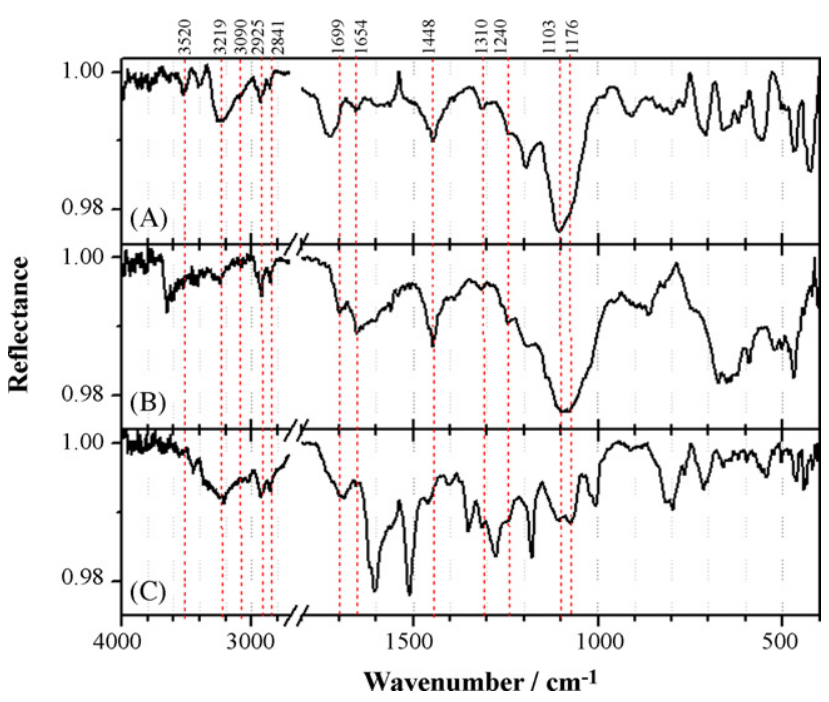

Fig. 8. Ex situ reflectance FT-IR spectra of the fouling film on: (A) Pt, (B) polyNiTSPP/Pt, and (C) polyNiTAPP/Pt electrode produced by 14,11 and 13 potential cycles, respectively, at $0.1 \mathrm{~V} \mathrm{~s}^{-1}$ in $1 \mathrm{mM} \mathrm{2,4,6-TCP}$ in the $\mathrm{pH} 11$ buffer electrolyte. 


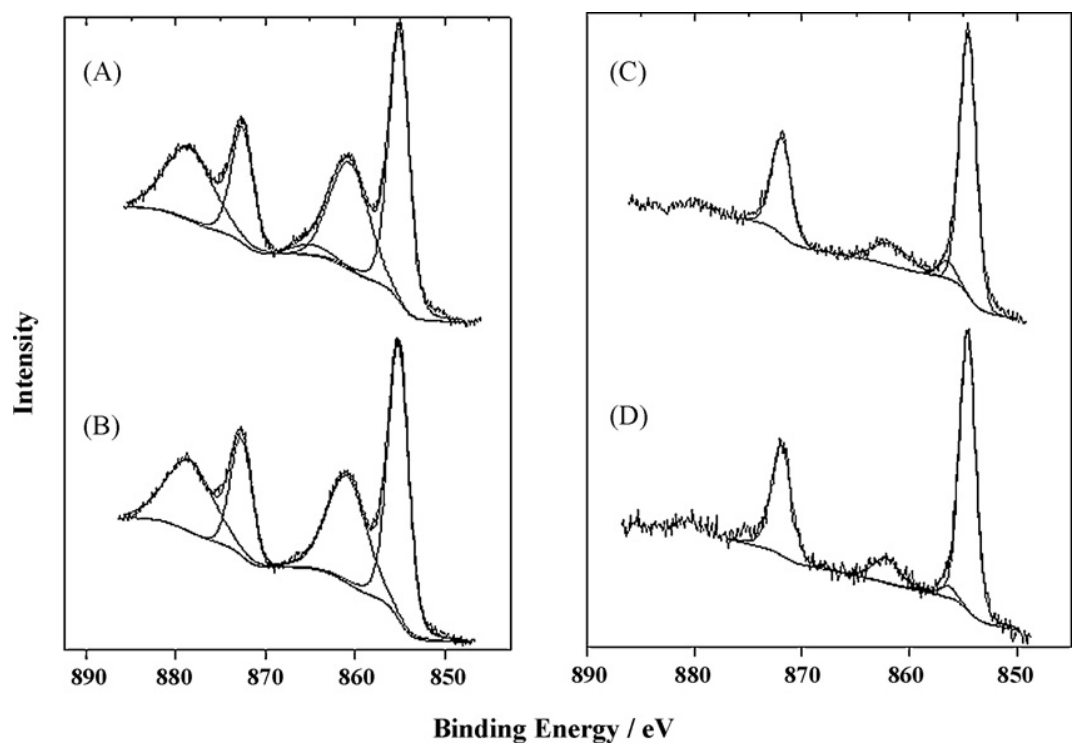

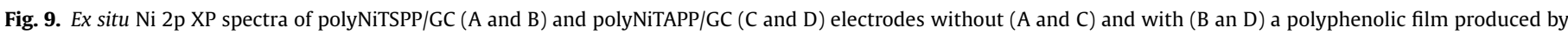
potential cycling at $0.1 \mathrm{~V} \mathrm{~s}^{-1}$ in $1 \mathrm{mM} 2-\mathrm{CP}$ in the $\mathrm{pH} 11$ buffer electrolyte.

2,4,6-TCP nor in the spectra of Fig. 8. Pei et al. [30] indicate that 2,4,6-TCP shows a ring C-C stretching band at $1473 \mathrm{~cm}^{-1}$, two bands at 1314 and $1225 \mathrm{~cm}^{-1}$ attributed to $\mathrm{O}-\mathrm{H}$ bending, and a band of $\mathrm{C}-\mathrm{O}$ stretching at $1284 \mathrm{~cm}^{-1}$. The $\mathrm{C}-\mathrm{C}$ ring stretch at $1473 \mathrm{~cm}^{-1}$ appears slightly shifted (at $1448 \mathrm{~cm}^{-1}$ in Fig. $8 \mathrm{~A}$ and B, respectively) in the fouling films on Pt and on polyNiTSPP/Pt, this band being very sensitive to changes in the electron distribution and symmetry of the ring. This band is absent in the spectrum of fouled polyNiTAPP/GC (Fig. 8C) because the oxidation currents of 2,4,6TCP were much lower than those at polyNiTSPP (Fig. 7D and C, respectively). The two weak bands at 1310 and $1240 \mathrm{~cm}^{-1}$ that appear in the three spectra of Fig. 8 could correspond to the two bands of $\mathrm{OH}$ bending of 2,4,6-TCP, but this cannot be true, because the $\mathrm{C}-\mathrm{O}$ stretch at $1284 \mathrm{~cm}^{-1}$ of 2,4,6-TCP does not appear in any of the three spectra. Most probably the band at $1310 \mathrm{~cm}^{-1}$ corresponds to a carboxylic acid, since these acids show a strong, mainly $\mathrm{C}-\mathrm{O}$ stretching, band [29] at $1315-1200 \mathrm{~cm}^{-1}$. The bending bands at 1637 and $1547 \mathrm{~cm}^{-1}$ of the amino groups [29] of the amino-

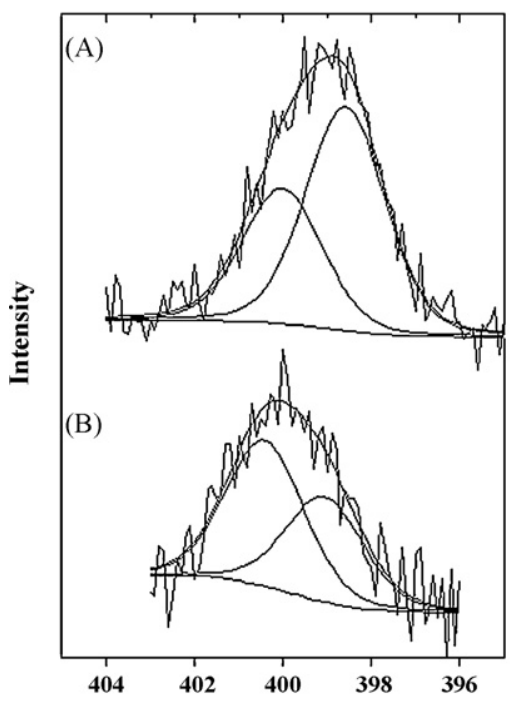

porphyrin clearly appear in the fouled polyNiTAPP/Pt electrode (Fig. 8C).

A band near $1700 \mathrm{~cm}^{-1}$ which does not appear in 2,4,6-TCP, should be due to the stretching vibration of an aliphatic $C=0$ group, which normally appears at $1800-1740 \mathrm{~cm}^{-1}$, but is usually shifted to lower wavenumbers if the ketone group is conjugated [29]. Obviously this band can appear only after the aromatic ring has been broken. The wide, intense band at $1103-1076 \mathrm{~cm}^{-1}$ could correspond to a $\mathrm{C}-\mathrm{O}$ stretch of one or several oxidation products of 2,4,6-TCP, and is less defined for polyNiTAPP/Pt, in which, as said above, the oxidation currents were smaller.

\subsubsection{Characterization of the fresh and fouled electrodes by X-ray photoelectron spectroscopy (XPS)}

X-ray photoelectron spectra of polyNimacrocycle/ITO electrodes, both fresh and fouled by $\mathrm{CP}$ oxidation products, were obtained. Ni was always present as $\mathrm{Ni}(\mathrm{II})$, since in these films $\mathrm{Ni}(\mathrm{III})$ is unstable [18]. The narrow-scan XP spectra of Ni 2p, N 1s and S 2s of

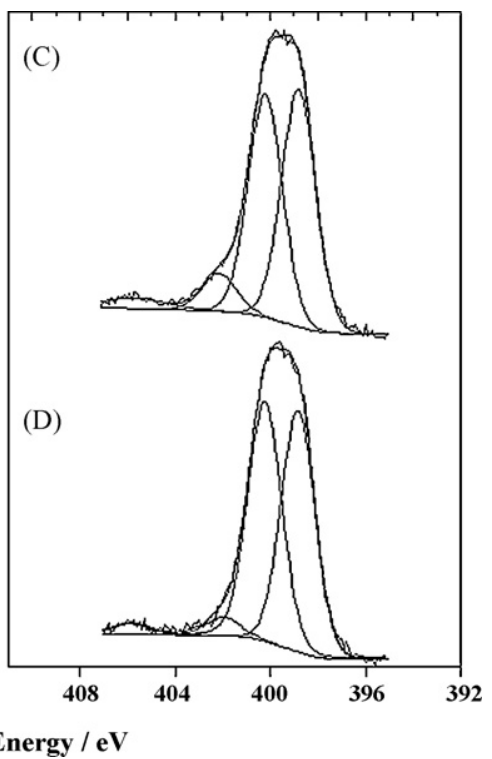

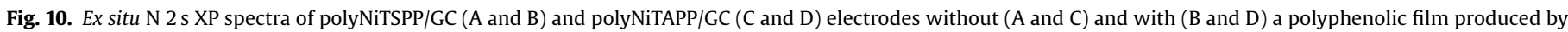
potential cycling at $0.1 \mathrm{~V} \mathrm{~s}^{-1}$ in $1 \mathrm{mM} 2-\mathrm{CP}$ in the $\mathrm{pH} 11$ buffer electrolyte. 
polyNiTSPP and polyNiTAPP films have been described [16,18]. Fig. 9 shows the Ni 2p spectra of polyNiTSPP and polyNiTAPP electrodes, both fresh and after cycling at $0.1 \mathrm{~V} \mathrm{~s}^{-1}$ in $1 \mathrm{mM} 2-\mathrm{CP}$ in the $\mathrm{pH} 11$ buffer electrolyte. The Ni 2p XPS spectrum of fresh polyNiTSPP is composed of a quite narrow spin-orbit doublet (Fig. 9A), with BEs of the Ni $2 p_{3 / 2}$ and $\mathrm{Ni} 2 \mathrm{p}_{1 / 2}$ levels of 855.0 and $872.6 \mathrm{eV}$, respectively, and a strong shake-up satellite structure at 860.7 and $878.7 \mathrm{eV}$. The results are consistent with the presence of paramagnetic $\mathrm{Ni}^{2+}$, as previously reported [16]. The Ni 2p XPS spectrum of polyNiTAPP (Fig. 9C) is composed of a narrow spin-orbit doublet with BEs of the $\mathrm{Ni} 2 \mathrm{p}_{3 / 2}$ and $\mathrm{Ni} 2 \mathrm{p}_{1 / 2}$ levels of 854.6 and $871.9 \mathrm{eV}$, respectively. These $\mathrm{BE}$ values and the almost total absence of prominent shake up satellites indicate that $\mathrm{Ni}$ in polyNiTAPP is mainly present as diamagnetic $\mathrm{Ni}^{2+}$. The tiny $\mathrm{Ni} 2 \mathrm{p}_{3 / 2}$ component at $856.5 \mathrm{eV}$ and the small satellite peak at $862.7 \mathrm{eV}$ might be indicative of the presence of a small $\mathrm{NiOOH}$ component, as we have also previously reported [16]. Inspection of Fig. 9 clearly shows that the spectra of the fresh electrodes are almost identical to those of the electrodes cycled in the presence of 2-CP, indicating that this cycling in 2-CP does not affect the chemical nature of the Ni species present in polyNiTSPP and polyNiTAPP.

Fig. 10 collects the $\mathrm{N} 1 \mathrm{~s}$ spectra of fresh polyNiTSPP and polyNiTAPP electrodes as well as the spectra of polyNiTSPP and polyNiTAPP electrodes cycled at $0.1 \mathrm{~V} \mathrm{~s}^{-1}$ in $1 \mathrm{mM} \mathrm{2-CP}$ in the $\mathrm{pH}$ 11 buffer electrolyte. As previously reported, the $\mathrm{N} 1 \mathrm{~s}$ spectrum of polyNiTSPP contains two contributions (Fig. 10A): one at $398.6 \mathrm{eV}$ (62\%), which we assign to pyrrolic nitrogen, and a second one at $400.1 \mathrm{eV}(38 \%)$, which we associate with the presence of $\mathrm{N}-\mathrm{H}$ bonds. As suggested before, the presence of $\mathrm{N}-\mathrm{H}$ bonds in polyNiTSPP might arise from some degree of demetallization of the original material. The $\mathrm{N}$ 1s spectrum of polyNiTAPP (Fig. 10C) contains, besides the two main contributions mentioned before, some minor contributions associated with shake up satellites $(402.1 \mathrm{eV})$ and inelastic scattering $(405.2 \mathrm{eV})$. When the polyNiTSPP electrode is cycled in the presence of 2-CP (Fig. 2B), there is a clear enhancement of the contribution at $400.1 \mathrm{eV}(58 \%)$ which we have assigned to $\mathrm{N}$ $\mathrm{H}$ bonds. Since this species has been associated with the presence of unmetallated porphyrin, it seems that cycling in 2-CP induces a high degree of demetallation. Inspection of Fig. 2D indicates that the same effect, although to a much smaller extent, is also observed in the polyNiTAPP electrode.

On Au modified with electrodeposited nickel hydroxide no oxidation of 2-CP occurrs, the only change observed being a slight positive shift of the peak of $\mathrm{Ni}(\mathrm{II})$ oxidation (results not shown). Probably the $\mathrm{Ni}(\mathrm{OH})_{2}$ particles were much larger than those in polyNiTSPc/GC electrodes. This subject deserves further investigation.

\section{Conclusions}

Anodic currents appear at potentials lower than that at which $\mathrm{Ni}(\mathrm{II})$ is oxidized (Fig. 2), showing that, due to the high porosity of polyNiTSPc films, oxidation of the CPs already occurs on the GC substrate, and also at the polyNiTSPc films when Ni is still present as $\mathrm{Ni}(\mathrm{II})$. The first electron transfer (certainly the rds) step of a completely dissociated $\mathrm{CP}$ is[4]:

$\mathrm{ArO}^{-} \Rightarrow \mathrm{ArO}^{\bullet}+\mathrm{e}^{-}$

where $\mathrm{ArO}^{-}$represents the phenolate anion and $\left(\mathrm{ArO}^{\circ}\right)$ the phenoxy radical.

The ex situ XPS results confirm, as already reported [16], that the sulphonated $\mathrm{Ni}(\mathrm{II})$ polymers contain $\mathrm{Ni}(\mathrm{OH})_{2}$, which is the electroactive species oxidized at the potential of peak IIa (Figs. 2 and 3 ):

$\mathrm{Ni}(\mathrm{OH})_{2}+\mathrm{OH}^{-} \Leftrightarrow \mathrm{NiOOH}+\mathrm{H}_{2} \mathrm{O}+\mathrm{e}^{-}$
The structure of both nickel species has generated much controversy in the literature, and probably changes with time (ageing), as proposed long ago for $\mathrm{Ni}(\mathrm{OH})_{2}$ electrodes [31]. Nevertheless, the changes in structure of polyNi electrodes are very slow compared to those observed for $\mathrm{Ni}(\mathrm{OH})_{2}$ electrodes, which disqualifies the latter as antifouling catalysts.

Once NiOOH has been formed, the phenolate anion could be oxidized by chemical reaction with $\mathrm{NiOOH}$ :

$\mathrm{ArO}^{-}+\mathrm{NiOOH}+\mathrm{H}_{2} \mathrm{O} \Rightarrow \mathrm{ArO}^{\bullet}+\mathrm{Ni}(\mathrm{OH})_{2}+\mathrm{OH}^{-}$

Whatever the precise role that $\mathrm{Ni}(\mathrm{OH})_{2}$ plays in the oxidation of chlorophenols, obviously the size and the concentration of $\mathrm{Ni}(\mathrm{OH})_{2}$ particles should affect the reaction. Further oxidation steps are very complex, probably different reaction paths occurring at the same time. The band of aliphatic $\mathrm{C}=\mathrm{O}$ stretching in the IR spectrum of the fouling film of 2,4,6-TCP (Fig. 8) signals a breaking of the aromatic ring, yielding ketones, aldehydes and/or carboxylic acids, and probably involving a partial dechlorination of the $\mathrm{CP}$ as proposed for the photocatalytic degradation of CPs [32].

The polyphenolic films produced in the oxidation of 2,4,6-TCP are very porous, as confirmed by the impedance measurements, allowing the oxidation to continue, while the other chlorophenols produce films of low porosity that impede further oxidation after one or two potential cycles. At the potential of $\mathrm{Ni}$ (II) oxidation the faradaic resistance for all the CPs is higher than that in the buffer electrolyte (Fig. 4D), indicating that even 2,4,6-TCP produces some fouling.

As already reported [16] the nature of the substituent, sulpho or amine, is the major factor affecting the activity of the electropolymerized films, only the latter requiring activation by potential cycling for the $\mathrm{Ni}(\mathrm{III}) / \mathrm{Ni}(\mathrm{II})$ process to appear in the CVs, but to a much lower extent than in the sulpho films. This is in agreement with the XPS results, which clearly show that the XP spectra of the sulphonated $\mathrm{Ni}$ (II) polymers are typical of paramagnetic $\mathrm{Ni}(\mathrm{II})$, indicating that they contained $\mathrm{Ni}(\mathrm{OH})_{2}$ clusters, while the XP spectra of activated amino films barely contained $\mathrm{Ni}(\mathrm{OH})_{2}$ clusters, since the $\mathrm{Ni}(\mathrm{II})$ in them was diamagnetic.

In the case of the amino substituent the nature of the Ni ligand, phthalocyanine or phenylporphyrin, also affects the activity of the film, the first ligand yielding a more active film, as can be seen by comparing Fig. 6B and D. Therefore, also the nature of the ligand affects the activity of the polymer film, although to a lesser extent than that of the substituent.

\section{Acknowledgement}

Financial support from FONDECYT-CONICYT-Chile, Grant 1070290, is gratefully acknowledged.

\section{References}

[1] J. Stradins, B. Hasanli, J. Electroanal. Chem. 353 (1993) 57.

[2] J. Han, R.L. Deming, F.-M. Tao, J. Phys. Chem. A 109 (2005) 1159.

[3] M.M. Fickling, A. Fischer, B.R. Mann, J. Packer, J. Vaughan, J. Am. Chem. Soc 81 (1959) 4226.

[4] C. Berríos, R. Arce, M.C. Rezende, M.S. Ureta-Zañartu, C. Gutiérrez, Electrochim. Acta 53 (2008) 2768

[5] M.S. Ureta-Zañartu, P. Bustos, C. Berríos, M.C. Diez, M.L. Mora, C. Gutiérrez, Electrochim. Acta 47 (2002) 2399.

[6] B. Agboola, T. Nyokong, Electrochim. Acta 52 (2007) 5039.

[7] M. Gatrell, D.W. Kirk, Can. J. Chem. Eng. 68 (1990) 997.

[8] M. Gatrell, D.W. Kirk, J. Electrochem. Soc. 139 (1992) 2736

[9] M. Gatrell, D.W. Kirk, J. Electrochem. Soc. 140 (1993) 1534.

[10] Z. Ezerskis, Z. Jusys, J. Appl. Electrochem. 31 (2001) 1117.

[11] Z. Ezerskis, G. Stalnionis, Z. Jusys, J. Appl. Electrochem. 32 (2002) 49

[12] R.D. Coteiro, A.R. De Andrade, J. Appl. Electrochem. 37 (2007) 691.

[13] G. Rosłonek, J. Taraszewska, J. Electroanal. Chem. 325 (1992) 285.

[14] A. Ciszewski, G. Milzarek, J. Electroanal. Chem. 469 (1999) 18.

[15] A.B.P. Lever, M.R. Hempstead, C.C. Leznoff, W. Liu, M. Melnik, W.A. Nevin, P. Seymour, Pure Appl. Chem. 58 (1986) 1467. 
[16] C. Berríos, J.F. Marco, C. Gutiérrez, M.S. UretaZañartu, J. Phys. Chem. B 112 (2008) 12644.

[17] S. Trevin, F. Bedioui, M.G. Gomez-Villegas, C. Bied-Charreton, J. Mater. Chem. 7 (1997) 923.

[18] C. Berríos, M.S. Ureta-Zañartu, C. Gutiérrez, Electrochim. Acta 53 (2007) 792.

[19] M.S. Ureta-Zañartu, A. Alarcón, C. Berríos, G.I. Cárdenas-Jirón, J. Zagal, C. Gutiérrez, J. Electroanal. Chem. 580 (2005) 94.

[20] M. Revenga-Parra, T. García, E. Lorenzo, F. Pariente, Sens. Actuators B 130 (2008) 730.

[21] M.S. Ureta-Zañartu, C. Berríos, J. Pavez, J. Zagal, C. Gutiérrez, J.F. Marco, J. Electroanal. Chem. 553 (2003) 147.

[22] J. Manriquez, J.L. Bravo, S. Gutierrez-Granados, S. Sucar Surcar, C. BiedCharreton, A. Alatorre Ordaz, F. Bedioui, Anal. Chim. Acta 378 (1999) 159.

[23] J. Obirai, F. Bedioui, T. Nyokong, J. Electroanal. Chem. 576 (2005) 323.
[24] M.S.P. Francisco, W.S. Cardoso, L.T. Kubota, Y. Gushikem, J. Electroanal. Chem. 602 (2007) 29.

[25] S.-Y. Yi, H.-Y. Cho, Y.C. Park, S.H. Lee, Z.-U. Bae, J. Electroanal. Chem. 602 (2007) 217.

[26] M.-W. Jung, K.-P. Kim, B.-Y. Cho, I.R. Paeng, D.W. Lee, Y.H. Park, K.-J. Paeng, Bull. Korean Chem. Soc. 27 (2006) 77.

[27] C. Berríos, G.I. Cárdenas-Jirón, J.F. Marco, C. Gutiérrez, M.S. Ureta-Zañartu, J. Phys. Chem. A 111 (2007) 2706.

[28] http://www.sigmaaldrich.com/spectra/ftir/FTIR008938.PDF.

[29] N.B. Colthup, L.H. Daly, S.E. Wiberly, Introduction to Infrared and Raman Spectroscopy", Third Edition, Academic Press, 1990, Ch. 9.

[30] Z-g. Pei, X-q. Shan, T. Liu, Y-n. Xie, B. Wen, S. Zhang, S.U. Khan, Environ. Pollut. 147 (2007) 764.

[31] F. Hahn, B. Beden, M.J. Croissant, C. Lamy, Electrochim. Acta 31 (1986) 335.

[32] H.-c. Liang, X.-z. Li, Y.-h. Yang, K.-h. Sze, Chemosphere 73 (2008) 805. 